\title{
RENEWAL AND PERSPECTIVES IN IRANIAN ARCHAEOLOGY OVER THE LAST TWO DECADES
}

\author{
Rémy Boucharlat \\ (Université de Lyon) \\ In memory of Olivier Lecomte \\ From Tureng Tepe to Ulug Depe a 45-year friendship
}

\begin{abstract}
These few pages provide a very schematic overview of archaeological research in Iran since the end of the 20th century. The recent evolution is sharply marked with the port-revolutionary period with a new policy and the emergence of new generations of numerous and well-trained archaeologists. Most of them are employed in the provinces and work on rescue excavations, which are increasingly organised upstream as preventive excavations, but also on multi-year programs to provide information on less known archaeological periods. The western half of the country is much better known and more studied than the eastern half, but the recent field research launched in the south, along the Persian Gulf, and in the northeast (Khorasan) is very promising.
\end{abstract}

\section{KEYWORDS}

Rescue archaeology, Joint expeditions, Archaeometry, New research áreas, Khorasan, South Iran.

\section{RÉSUMÉ}

Ces quelques pages offrent un tableau très schématique de la recherche archéologique en Iran depuis la fin du 20 e siècle. L'évolution est extrêmement marquée avec la période post-révolutionnaire avec l'émergence de nouvelles générations d'archéologues nombreux et bien formés. La plupart sont employés dans les provinces et travaillent sur des fouilles de sauvetage de plus en plus organisées en amont en fouilles préventives mais aussi sur des fouilles programmées pluriannuelles destinées à informer sur les périodes archéologiques moins bien connues. La moitié ouest du pays est mieux connue et plus étudiée que la moitié est, mais les recherches récentes impulsées dans le sud, le long du golfe Persique, et dans le nord-est (Khorasan) sont très prometteuses.

\section{MOTS CLÉS}

Fouilles de sauvetage, Programmes bilatéraux, Archèométrie, Nouveaux terrains, Khorasan, Sud de l'Iran.

From the Iranian revolution of 1979 until the mid-1990s, there had been relatively few planned excavations but mainly rescue operations; they were carried out by Iranian teams only. Then, by the end of the $20^{\text {th }}$ century, the arrival of a new generation of young archaeologists coincided with a shift in Iranian archaeological policy towards more numerous operations $(\S 1)$. In this presentation, I try to highlight some of the profound changes and to give a quick overview of the many results of archaeological research in Iran to be compared to the 20 -year period following the 1979 Revolution. ${ }^{1}$

This policy was largely driven by the need to carry out very numerous rescue excavations in areas undergoing rapid urbanisation or in mountain valleys where many dams were under construction or planned $(\$ 2)$.

Shortly before the year 2000, the cultural authorities allowed the establishment of some bilateral missions between an Iranian team and a foreign team, from universities of half a dozen European countries, generally for operations limited in time, 2 to 3 years, and directed towards rescue excavations $(\S 3)$.

The majority of Iranian missions have largely given preference to ancient periods, from the Neolithic to the Bronze Age included. Among more recent periods, the Iron Age,

\footnotetext{
1 I had the opportunity to present in Madrid, already at the invitation of Prof. Córdoba, a report on archaeological research in Iran from the Revolution to 1996 (Boucharlat 1998a). The comparison of the results in the two periods is very significant.
} 
which in Iran corresponds to the arrival of the Iranian populations, has been favoured. The other so-called "historical" periods, the empires up to the coming of Islam and the medieval and modern periods have rarely been treated as part of a research programme, but more often in the frame of rescue operations. The situation is gradually changing $(\S 4){ }^{2}$

Finally, a very remarkable innovation was the launch of operations in regions that had hitherto been little explored, the Central Plateau, where the famous Sialk site remained quite isolated, the Persian Gulf and the huge north-eastern quarter of the country, mainly the three provinces of Khorasan ( $(5)$.

\section{The actors}

After a few years of interruption after the 1979 revolution, teaching of archaeology resumed in Iran, supervised by the few professors who had acquired their doctorates abroad in the 1970s, as had Prof. E. Neghaban a generation before these seniors archaeologists. The activity of these specialists has made it possible to increase the number of teaching places in state universities and in several so-called private (Azad) universities. These teachers trained contingents of young archaeologists, many of whom obtained their doctorate within the next decade and who are able in turn to teach. Now two generations of archaeologists are well trained in modern archaeological methods and techniques. Many archaeologists have chosen specializations, such as the disciplines of archaeometry, including geophysical prospecting, chemical analysis, palaeobotany, archaeozoology, etc. The framework for field research can be considered to be of a satisfactory level to meet the research and excavations requirements imposed by the country's modernisation.

\section{Scheduled and rescue excavations}

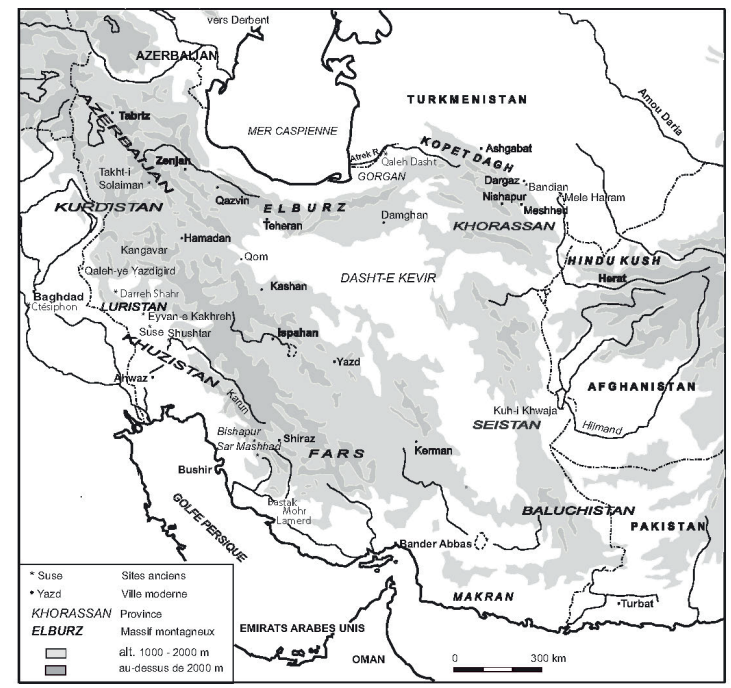

Figure 1. General map of Iran showing the main administrative provinces (R. Boucharlat).

2.1. The planned excavations have been few in number, and often have been the resumption of work undertaken before the revolution

Sialk was taken over in 2001 for 5 years by the "Sialk Reconsideration Project", for throwing light on the unclear excavations on this major site by the French archaeologist

\footnotetext{
2 In 1997, the ICAR (Iranian Center for Archaeological Research) resumed the tradition of annual symposia presenting the results of archaeological research of the past year. These symposia became systematic in 2004 (in 2019 the 16th symposium was held). They are published in Tehran, in the form of a few articles but mainly as one- or two-page summaries, usually in Persian. Articles and reports published in English in international journals in Iran and Western countries are increasingly numerous and are now available to all. The bibliography would be immense. The titles mentioned here are very selective to serve as an example.
} 
R. Ghirshman in the 1930s. One of the objectives was to verify the date of the "great construction" in mud bricks dated to the 1st millennium by Ghirshman. On the basis of soundings, the excavators proposed a new date for a construction in the 3rd millennium. According to the season of a second team however, the date finally returned to the $1 \mathrm{st}$ millennium BC. New research on the 3rd millennium includes Shahdad, at the end of the 3rd millennium, on the edge of the Lut desert (1995-1998), or Shahr-e Sokhte, on the Afghan border, for the end of the 4th-early part of the 2nd millennium, from 1997 onwards; geophysical surveys at the Middle Elmaite palace and necropolis of Haft Tepe, in Khuzestan, surveys and excavations at Choga Zanbil nearby, since 1999, a UNESCO Heritage site. 3 The hill of Tepe Hegmataneh, supposed to be the seat of the Median and Achaemenid Ecbatana in the modern city of Hamadan had been prepared for the excavations by purchasing the inhabited land before the revolution.

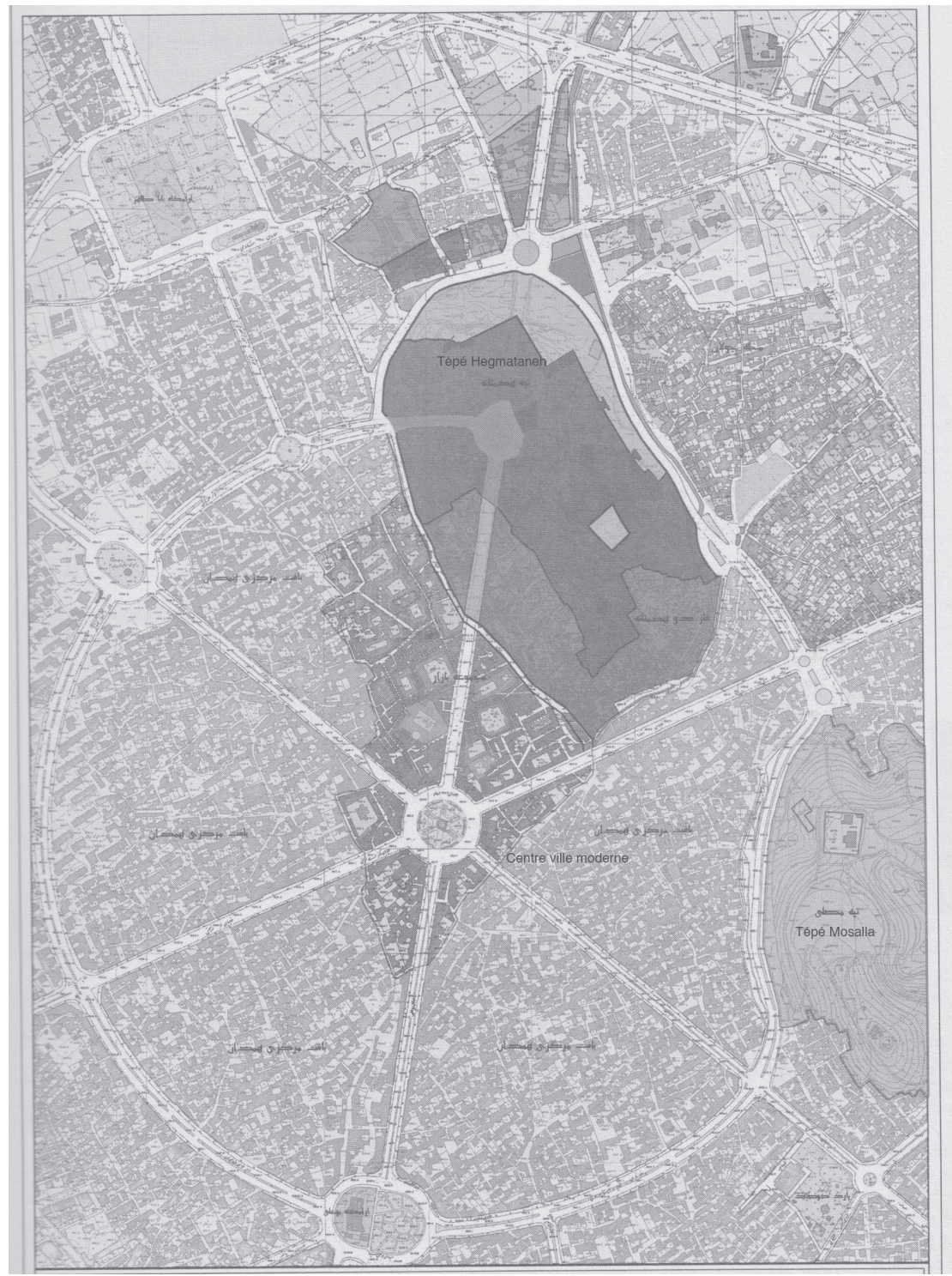

Figure 2. Plan of Tepe Hegmataneh near the city center of modern Hamadan. Median and Achaemenid Ecbatana may be buried under the other hill, Tepe Mosala, to the right (Boucharlat 2018, fig. 1).

It was then excavated on a large scale between 1983 and 2000 during 12 campaigns, then again by precise soundings in 2004-2007 which revealed that the famous city was not

3 See the series Elamica edited by B. Mofidi Nasrabadi, Hildesheim, Verlag Franzbecker, since 2011. 
on this hill; it was only occupied from the Parthian period for a short period, marked by a series of very similar architectural units in a very regular urban planning. These discoveries are still waiting to be explained, while the Achaemenid Royal city remains elusive but certainly existed. ${ }^{4}$

\subsection{Rescue excavations}

The modernisation of the country in urban areas (new buildings in city centres, extension of urbanisation), as well as in the countryside (dams, roads, railways, mechanisation of agriculture), but also the looting of archaeological sites has required many archaeological interventions, some of them of short duration, others over several seasons, or sometimes transformed into long-term planned excavations. Short operations on sites already excavated, such as Tepe Hissar (1996-97) in the north, cut in half by the doubling of the railway line; in Susa (1995-1998) facing the extension of the modern city at the foot of Darius' palace. ${ }^{5}$ Dahan-i Ghulaman, excavated in the 1960s by the Italians, had to be re-explored following the construction of huge reservoirs of the Helmand river. The 2000-2005 rescue operations were followed by more limited excavations. ${ }^{6}$

Several sites in the southern region of Tehran were threatened with destruction, such as Tepe Pardis (late Neolithic and transitional Chalcolithic, mainly until the Iron Age) excavated in 2005-07, or in the same Tepe Ma'mourin area, an Iron Age site. In Azerbaijan, the site of Bukan/Qalaychi south of Lake Orumiyeh, at short distance from Hasanlu, was excavated before and after 2000, following two periods of severe looting. It has yielded the oldest known Aramaic inscription east of the Tigris, dated from the 8th century BC as well as many decorated glazed bricks. ${ }^{7}$ On the Iranian Plateau, Qole Darvish near the city of Qom excavated since 2003, was important for the 4th and 3rd millennia, including the proto-Elamite period. ${ }^{8}$ Bandiyan, North Khorasan, was discovered in 1994 and revealed to be a major Sasanid site. ${ }^{9}$

The best-known example of a project first launched as rescue excavation is Konar Sandal, near Jiroft, south of Kerman, because of the spectacular discoveries and results. In 2001, exceptional floods uncovered a 3rd millennium cemetery showing the funeral material on the surface. The intense looting of extraordinary chlorite vases and objects from hundreds of tombs caused heavy archaeological intervention from 2002 to be carried out on neighbouring sites, habitats and large monuments including a huge stepped terrace, while other contemporary cemeteries were protected pending exploration (they have not yet been excavated in 2017). Jiroft reveals a "civilization" of eastern Iran that has been suspected from Mesopotamia since long, but is now located and illustrated by remains and an artistic production showing an amazing iconography.

4 Sarraf 2003, Azarnoush 2007; Boucharlat 1998; 2012; 2018.

Kaboli 2000.

6 General presentation in Gnoli 1993; for a view on the most recent works see Sajjadi, Zebari 2018.

7 Among an abundant literature, easy access to Hassanzadeh \& Mollahsalehi 2011. A catalogue of more than 200 bricks seized by the police has been published in 2018 (in Persian).

8 Alizadeh, Aghili, Sarlak 2015.

9 Rahbar 1998, 2004, 2007. See below. 

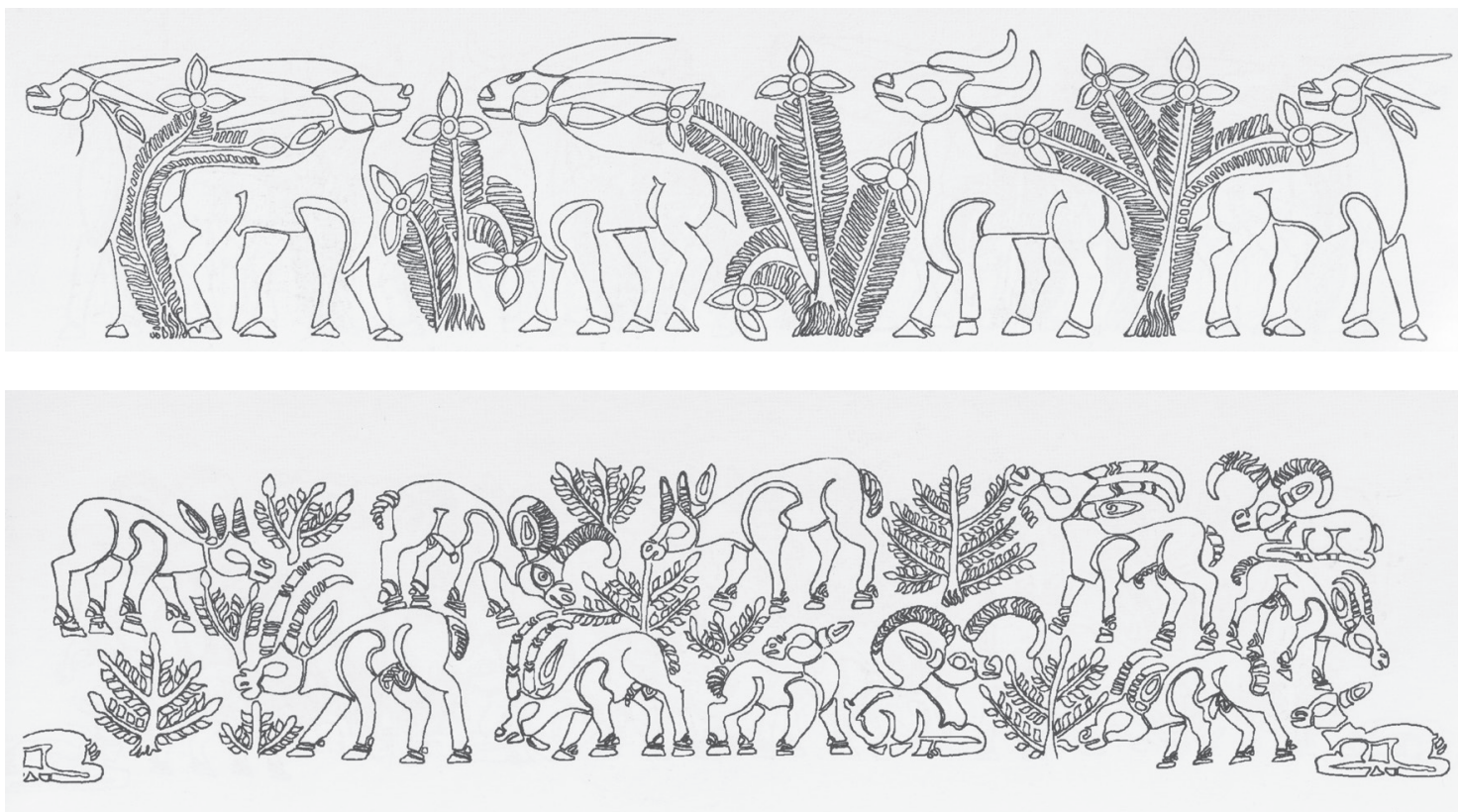

Figure 3. Jiroft. Two examples among dozens chlorite vases seized by the police after the plundering of the necropolis (Perrot and Madjidzadeh 2005, fig. 4e and f.) ${ }^{10}$

The country of Aratta mentioned in the cuneiform texts remains an enigma however, even if Jiroft's main excavator, Y. Majidzadeh, locates the antique country in Jiroft valley (Jazmourian) and its the centre on the site itself.

Less well known, but very important historically, the vast exploration programme of the Bam oasis followed the tragic earthquake of December 2003. Bam itself was a very well preserved medieval and modern city. Recent analyses carried out inside destroyed walls show that some parts date back to the 8 th-7th century BC. The area was archaeologically terra incognita and the rather late (historical) occupation was attributed to the fact that it is located in an arid area (about $60 \mathrm{~mm}$ annual rainfall), where only the implementation of water acquisition techniques allowed sedentary people to survive. Bam area is now known to have been occupied since the Neolithic and Chalcolithic Bronze Age, once in a slightly more favourable environmental context, and in historical times since the Achaemenid period. Several programs are underway, but very little is published until now.

In the central and southern parts of the Zagros range, dozens of dams have caused rescue programmes over entire valleys. Near Pasargadae, for the first time, these excavations were transformed into an international programme (2005-2007), with five foreign teams (Germany, France, Italy, Japan, Poland). In this valley, Tang-i Bolaghi, very close to Pasargadae, the results are important for the Chalcolithic period (Bakun) and for the Achaemenid period. ${ }^{11}$

\section{New policy}

The new research strategies put in place around 2000 launched rescue operations that gradually became preventive excavations, thus giving more time to the field research. These policy has also made possible to launch several joint missions:

- With Japan, on the west bank of the Sefid Rud River in Gilan (mainly Iron Age), and Prehistoric research in Fras, near Persepolis.

10 Majidzadeh, Perrot 2004, Perrot, Madjidzadeh 2003; 2005.

11 For the latter see Boucharlat, Fazeli Nashli 2009; Askari Chaverdi, Callieri 2016. 
- With Germany in Arisman, southeast of Kashan, a very important site of late 5th/early 4th millennium copper work until mid-3rd millennium (2000-2004) ${ }^{12}$ and in Veshnaveh near Qom, a mining site and votive place explored between 2002 and 2005. ${ }^{13}$ More recently, Tepe Gohar in Mazanderan, is an important site excavated between 20082012 for its settlement from the Early Bronze Age and its late Bronze Age necropolis; $;{ }^{14}$ Tepe Rivi in North Khorasan, a Bronze Age and Iron Age site studied since 2015, which has not yet been reported.

- With France; surveys in Pasargades, 1999-2008, and resumed in 2015, and in the Persepolis plain between 2005 and 2008..$^{15}$

- With Italy in Pasargadae for a while, then in the Persepolis plain since 2008. ${ }^{16}$

- With Australia, in the Mamasani region on the border of Fars and Khuzistan, $2003-2008^{17}$

- More occasional collaborations with archaeologists from the United Kingdom in the Tehran region and western Iran for the Neolithic and Chalcolithic periods. These joint programmes, some of which are still ongoing, concerned sites, threatened or not, but which were considered of primary importance by the authorities of the Cultural Heritage Organisation (ICHHTO) ${ }^{18}$ as part of a scientific research policy.

At the same time, it should be stressed that these foreign countries and Iran have activated the long delayed publications, of excavations prior to 1979, in the Central Zagros, Bisutun published in 1996. ${ }^{19}$ Neolithic and later periods of Tepe Guran (Mortensen 2014), the Median site of Nush-i Jan (Stronach \& Roaf 2007), Godin Tepe (Gopnik \& Rothman 2011), and the impressive publication of the necropoles of Luristan between the end of the 4th and the 1st millennium BC (Haerinck \& Overlaet 1996-2010, 8 volumes). We should also mention the publication, especially the 5 th and 4th millennium excavations of Choga Mish in Khuzistan (Alizadeh 1996; 2008), Choga Bonut in the same region, re-excavated in 1996 (Alizadeh 2003) and the Achaemenid palace of Susa (Perrot 2010). In Fars, in the Persepolis region, let us mention Tal-e Malyan (Carter 1996; Sumner 2003). In eastern Iran, two more volumes have been published for Tepe Yahya (Lamberg Karlovsky and Potts 2001; Magee et al 2004).

The ongoing work of the few joint missions and even more so of the very many Iranian missions has produced hundreds of reports and articles and already a few volumes published between 2003 and today: Tol-e Bashi, Neolithic site of the Persepolis Plain, survey and soundings in the Sefid Rud/Jalaliyeh Valley in Gilan (Iron Age), survey and soundings in the Mamasani region, Western Fars (all periods), survey of the Mianab Plain, near Shushtar (Moghaddam 2005), Lama necropolis, late 2nd and early 1st millennium in the Yasuj mountain region (Rezvani et al. 2007 ); Surkh Dum Laki, an Iron Age and Parthian site in Luristan (Shishegar 2006), and rescue excavations in the Tang-i Bolaghi near Pasargadae and survey and soundings in Persepolis West (already mentioned for the Achaemenid period) and many others, published in the Archaeological Report Monograph Series. Unfortunately these publications are in Persian and not very accessible for the readers outside Iran; others books published by provincial universities, also in Persian,

\footnotetext{
12 Helwing et al. 2011.

13 Bagherpour-Kashani \& Stöllner 2011.

14 Mahfrouzi \& Piller 2009.

15 Benech, Boucharlat, Gondet 2012; Boucharlat, De Schacht, Gondet 2012. Boucharlat in press.

16 Askari and Callieri 2017. For the Achaemenid monumental gate under excavations since 2011, see Askari Chaverdi, Callieri, Matin 2017.

17 Potts et al. 2006; 2008; 2009.

18 Iranian Centre of Heritage, Handicrafts and Tourism Organization, and within it RICHT (Research Iranian Center Heritage and Tourism).

19 Kleiss, Calmeyer 1996. Only final publications published from 1996 onwards are mentioned here.
} 
are even less available, such as the survey of a valley of the southern Fars near the Persian Gulf, as well as an excavation on a circular moated Sasanian site (now some information on this site, Asadi et al. 2014, and more generally on this area in the Sasanian- early Islamic periods in Asadi et al. 2013).

These works, whether they are bilateral or exclusively Iranian are carried out according to the methods and tools of contemporary archaeological research. Specialists in these methods and techniques are more and more often well trained Iranians. Geophysical prospecting methods are now very frequently applied either as a preventive measure or before excavations are undertaken, as well as other tools and methods, such as GIS, which are very widespread, at varying levels of development, or the processing of satellite and aerial photographs. Environmental studies have become an integral part of the programs for all teams.

\section{An impossible inventory}

Given the enormous amount of operations carried out in the last 20 years, it is impossible to present tables by periods. Only a few of the most significant have been mentioned above. There have been hundreds of operations since 2000, small, medium and large. It was noted that many field operations, usually quite short in a single year or a few seasons, were very often conducted on a rescue basis.

Some remarks can be made on the main orientations of the current archaeological research. The Neolithic period is quite favoured, such as the plain of Ilam and the Kermanshah-Islamabad region, near the Iraqi border, the Persepolis plain, the Tehran region and the Qazvin region, and more recently the Khorasan. The Chalcolithic and Bronze Age are studied in the same regions, as well as in the Western Fars, now including Khorasan. It should be noted that these ancient periods are very poorly represented in the warm regions of southern Iran and along the Persian Gulf, because they are not very present according to the surveys results. In the Khuzistan plain, settlements date back to the Neolithic period. For the Chalcolithic, in addition to the many known villages, an exceptional series of collective tombs from the end of the 5 th millennium. BC was quite recently discovered at Tol Choga Sofla on the Zohreh River in the eastern part of the province. These are built in mud bricks, baked bricks, which is quite exceptional for that period, and in stone. The painted pottery is the distinctive one of the Susiana period (Moghaddam 2016).

In the same region, farther east, near Ram Hormuz, a new neo-Elamite tomb has been found in 2007 (Shishegar 2015). It is dated from $7^{\text {th }}$ or 6th century (the latter date is preferred by the excavator) contemporary with the rather similar Behbahan tomb discovered in 1982. As the latter the vaulted underground vaulted tomb built in mud bricks contained two "bath tub" sarcophagi in bronze yielding exceptionally rich objects of ornament in, gold, bronze vases, some of them glazed.

For the Iron Age I-III, they are mainly necropolises: in the Meshkin Shahr region near the border with the Republic of Azarbaijan, in the Talesh, west of the Caspian Sea, Tabriz region, Kul Tarike in Kurdistan, Sangtarashan in Luristan. The settlements are very rare in these regions. Conversely for the more recent Iron Age (Iron III) there are the socalled "Median" settlements (8th-7th centuries) in the Central Zagros, around Hamadan, and in the western part of the Iranian Plateau, characterized by a "fort" with long parallel rooms. They counts now half a dozen of sites labelled Median in the Hamadan region, considered to be the centre of this Median culture, as well as farther east on the Iranian Plateau in Tepe Ozbaki and in the Qom region. 


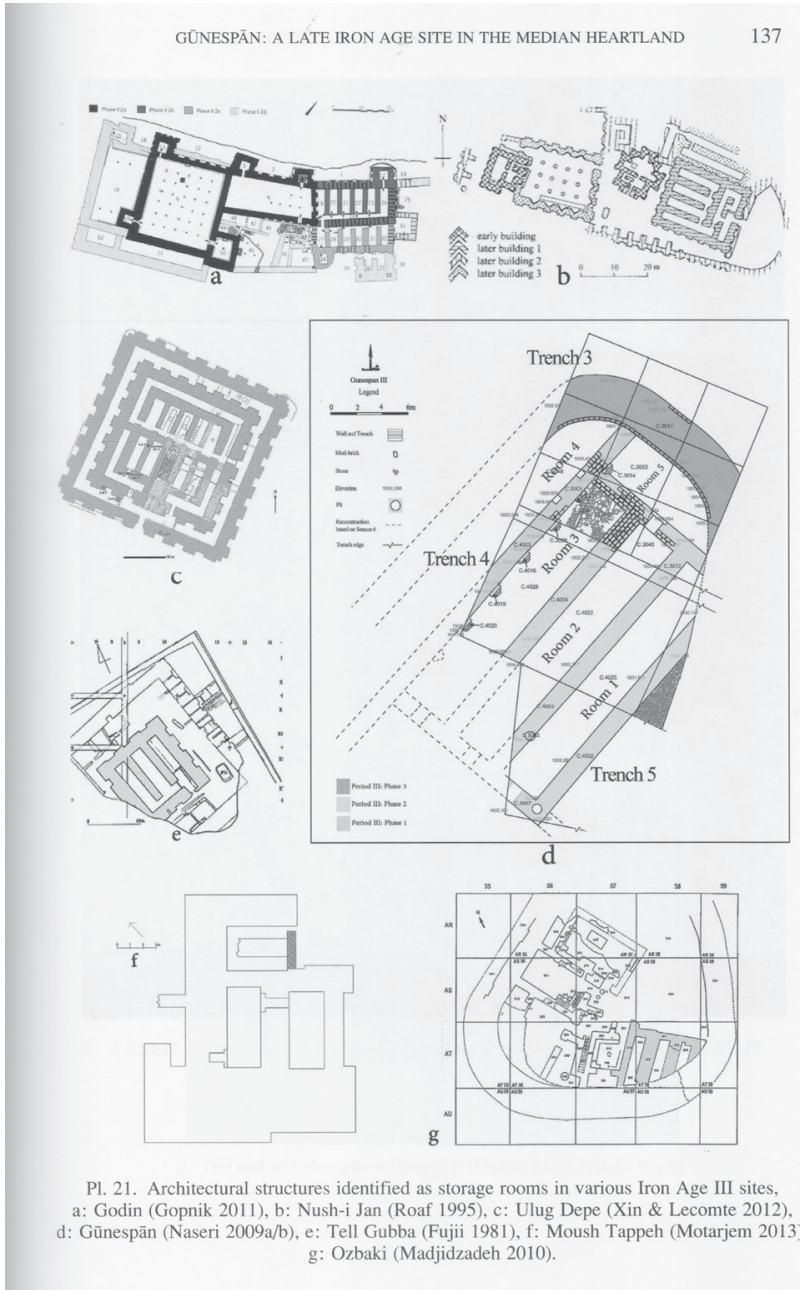

Figure 4. Plans of a series of so-called Median forts sharing some common features (Naseri, Malekzadeh, Naseri 2016, Pl. 21).

This culture poses a problem of chronological limits (their date are considered restricted in the 8th-7th century BC) and a geographical problem because of the extension with some very distant sites at $2000 \mathrm{~km}$ like Ulug Depe in southern Turkmenistan (Boucharlat et al 2005; Lecomte 2013).

Achaemenid sites are surprisingly rare (apart from the well known royal sites), although the some porticoed buildings such as Qaleh Kali, Mamasani region and the series of "palaces" in the south near Bushir has brought to light new elite building. ${ }^{20}$ Recent research has not provided much additional information on ordinary habitat sites except in the Tang-i Bolaghi valley of Pasargadae, already mentioned: on different sites, a small village, one or two farms (?) and a élite pavilion with stone column bases have been brought to light (see fn. 10). This experience suggests that this period is identifiable if the archaeologists actually look for it. The Parthian period also remains very poorly known in Iranian chronology. On the other hand, the Sasanian period has seen real progress. We have mentioned the discovery, then the long-term excavation, of Bandian, north of Mashhad in Khorasan, with a residence or memorial building with a private fire temple with impressive stucco figurative decorations,

20 The distinctive Achaemenid plan hall with four corner towers is now shown in the far eastern site of Dahan-i Ghulaman (Mohammadkhani 2012) in Sistan, near the Afghan border, and in, Bam are (Atayi, Zare 2019). 


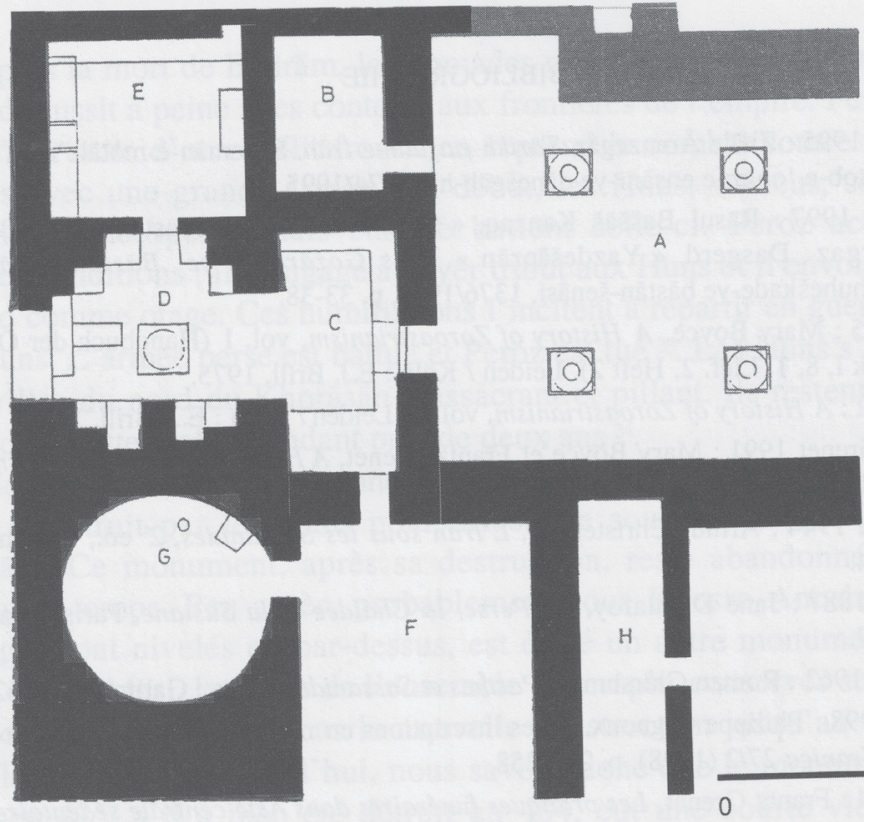

Figure 1. Plan général du temple; A- salle de réunion; B- salle des

Figure 5. A) Plan of the ritual Sasanian building of Bandian, Khorasan. Note the small cruciform fire temple in the center (Rahbar 2004, fig. 1); B. One of the stucco panel of the main hall of Bandian (Rahbar 1998, fig. 6).

an administrative building (?) and a compartimented tower considered by the excavator a "Tower of Silence" for the deposition of the dead in the Zoroastrian religion (see $\S 1$ ). At the other end of Iran in the Saimareh Valley, Ilam province, near the Iraqi border, rescue excavations have revealed buildings (élite residences?) with stuccoes with floral motifs or animal representations of the late Sassanian period or early Islam. In several regions (Central Zagros, Fars and Khorasan), a dozen Zoroastrian religious monuments of the Chahar Taq type (four arches supporting a dome) have been the subject of extremely productive rescue excavations.

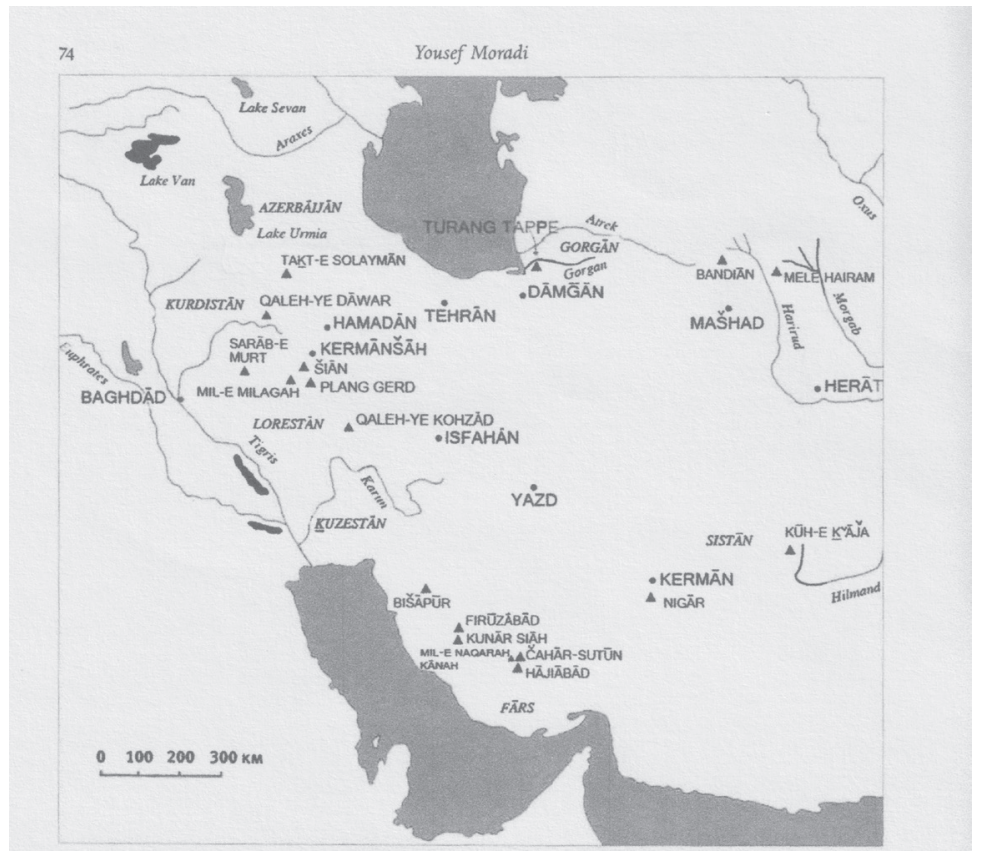

Figure 6. Distribution map of the excavated Sasanian chahar taqi, considered as fire temples according to the inner installations (Moradi 2016, fig. 1). 
They all show that the furnishing (central altar, tables, plateforms, etc.) very likely corresponds to local Zoroastrian fire temples (Boucharlat 2014; Alibaigi, Khosravi, Rashno 2018).

A review of all this work would be an enormous task, judging by the only attempt published in the German journal AMIT (Azarnoush \& Helwing 2005) which only covered periods from the Neolithic to the Iron Age included up to 2003. This panorama would be more than double today for these periods and it would be necessary to add a panorama of the sites of the later periods $1^{\text {st }}$ mill. $\mathrm{BC}$ and forst half of the $1^{\text {st }}$ mill. AD.

\section{Perspectives}

For the future, two hitherto little-known regions are called upon to profoundly renew our knowledge of Iranian archaeology:

Immense Khorasan covers a large part of the northeast quarter of the country and corresponds to three administrative provinces (South Khorasan, North Khorasan and Khorasan Razavi); two other smaller provinces must be added, Golestan (formerly Gorgan) on the border with Turkmenistan, and to the south of the Elburz range, Semnan province. In the two latter regions, previously excavated sites, Tepe Hissar in the south, Tureng Tepe and Shah Tepe in the north, remained important but isolated landmarks.

In Khorasan, the archaeological research is in its very beginning. Sometimes it was the urgency of the rescue excavations that led teams to work in these regions, but the dynamics of the research was certainly stimulated by the results obtained in what was until 1991 Soviet South Central Asia (today Turkmenistan, Uzbekistan and Tajikistan), for the Neolithic and Bronze Age period corresponding to the Civilization of the Oxus or BMAC (Bactria-Margiana Archaeological Complex) whose flowering was between 2500 and 1800 BC. For both periods, the architecture and the material are very different from the cultures of the corresponding periods on the Iranian Plateau. It is therefore the question of the borders between the two cultures that is being sought in northern and north-eastern Iran. They are gradually taking shape, with mixed areas now appearing in western Khorasan and Golestan (Vahdati 2017; 2018). The comparison between the two regions at subsequent times will also be an important theme for future research: Nisa in Turkmenistan, the country of origin of the Parthian dynasty, from the 2nd century BC, before its expansion into Iran is not very far from the Iranian border.

South-eastern Iran, where the security situation is not very favourable to field research, remains little explored. Along the Persian Gulf several surveys have revealed the potential of that areas especially for the historical periods. The present day economic development of coastal ports and islands has required some rescue excavations. In the interior, in the valleys parallel to the coast, surveys and some excavations reveal a very low occupation in the protohistoric period, up to and including the Iron Age, and then a long settlement process that begins in the Achaemenid period but which is more marked in the Parthian period and will reach its peak in the Sasanian period and during the first centuries of the Islamic period. This development process in these hot and arid areas is relatively more limited than in other parts of Iran, regardless of the environment. As in the case of north-eastern Iran, whose research has been stimulated by the development of research in South Central Asia, it is likely that archaeological research in southern Iran is now being stimulated by the very important results obtained in the countries on the Arab shore of the Persian Gulf, from Bahrain to Oman, for the different periods, from the 5th millennium BC to the first centuries of our era.

The emergence of these vast regions as terra incognita into the field of archaeological research in Iran is certainly the major phenomenon of the recent years. The very first results obtained by several teams show that it is from these regions, and particularly from the 
whole of the north and northeast of Iran, that the most important and newest contributions will come in the coming years.

\section{References}

Alibaigi, S., Khosravi, Sh., Rashno, A., 2018, “Ossuary of Palang Gerd Fire Temple: New Evidence of Zoroastrian Funerary practices during the Sasanian Period in Western Iran, Kermanshah", Studia Iranica 47/1, pp. 51-73.

Alizadeh,A., 2003, Excavations at the Prehistoric Mound of Choga Bonut, Khuzestan Iran. Seasons 1976/77, 1977/78, and 1996 (OIP 120), Chicago.

Alizadeh, A., 2008, The Development of a Prehistoric Regional Center In Lowland Susiana, Southwestern Iran . Final Report on the last six Seasons Of Excavations, 19721978 (OIP 130), Chicago.

Alizadeh, A., 2014, Ancient Settlement Systems And Cultures In The Ram Hormuz Plain, Southwestern Iran. Excavations at Tall-e Geser and Regional Survey of the Ram Hormuz Area (OIP 140), Chicago.

Alizadeh, A., Aghili, Sh. and Sarlak, S., 2015, "Highland-Lowland interaction in the

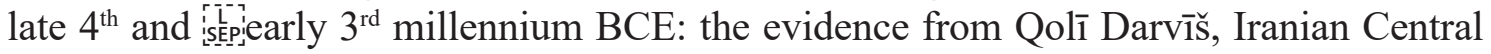
Plateau", AMIT 47, pp. 149-168.

Álvarez Mon, J. and M. B. Garrison (eds.), 2011, Elam and Persia. Eisenbrauns: Winona Lake, Indiana. London

Álvarez Mon, J. Basello, G.P., Wicks, Y., 2018, The Elamite World, Routledge,

Asadi, A., Mousavi Kouhpar, S.M., Neyestani, J., Hojabri-Nobari, A., 2013, "Sasanian and Early Islamic settlement patterns north of the Persian Gulf", Vicino Oriente XVII, pp. 21-38.

Asadi, A., Mousavi Kouhpar, S.M., Neyestani, J., Hojabri-Nobari, A., 2014, “A Recent Late Sasanian Discovery north of the Persian Gulf. A Report on the First Season of Excavations at Tomb-e Pargan in Hormozgan, Iran", Anabasis, Studia Classica et Orientalia 5, pp. 122-138.

Askari Chaverdi,A. \& Callieri, P., 2016, Tang-e Bolaghi (Fars), Sites TB76 et TB77: Rural Settlements of the Achaemenid and Post-Achaemenid Periods. Report of the archaeological rescue excavations carried out in 2005 and 2006 by the joint IranianItalian mission of the Iranian center for Archaeological research and the University of Bologna with the collaboration of IsIAO, Italy, (BAR International Series 2799), Oxford.

Askari Chaverdi, A., Callieri, P., 2017, Persepolis West (Fars, Iran): Report on the field work carried out by the Iranian-Italian Joint Archaeological Mission in 2008-2009 (British Archaeological Reports International Series 2870). BAR Publishing

Askari Chaverdi, A., Callieri, P., Matin, E., 2017. "The Monumental Gate at Tol-e Ajori, Persepolis (Fars): New Archaeological. Data. G.P. Basello, Two New Fragments of Cuneiform Inscriptions on Glazed Bricks from the Iranian-Italian Excavations at Tol-e Ajori (Fars)", Iranica Antiqua 52, 2017, pp. 205-258.

Atayi, M.T., Zare, Sh., 2019, "A new Achaemenid building-complex in

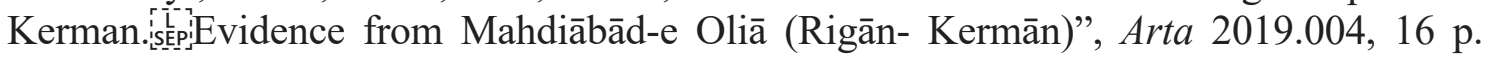
http://www.achemenet.com/document/2019.004-Atayi_Zare.pdf

Azarnoush, M., 2007, "Report on the excavations on Tappeh Hegmataneh, Hamadan", in The $9^{\text {th }}$ Annual Symposium on Iranian Archaeology (Archaeological Reports 7/1), Tehran, pp. 21-60 (in Persian).

Azarnoush, M. \& Helwing, B., 2005, "Recent archaeological research in Iran Prehistory to Iron Age", AMIT 37, pp. 189-246. 
Bagherpour-Kashani and Th. Stöllner (eds), 2011, "Water and caves in Ancient Iranian religion: Aspects of archaeology, cultural history and religion. Workshop in the "Kunstsammlungen" at the University of Bochum, 2008", AMIT 43, pp. 1-168.

Benech, Ch., Boucharlat, R., Gondet, S., 2012, "Organisation et aménagement de l'espace à Pasargades : Reconnaissances archéologiques de surface, 2003-2008", ARTA $2012.003 \mathrm{http} / /$ www.achemenet.com/document/2012.003-Benech_Boucharlat_Gondet. pdf

Boucharlat, R. 1998a, “L'Iran au Ier millénaire avant JC. Recherches iraniennes récentes", in J.M. Córdoba Zoilo ed. Actas del I Symposium Internacional, Una década de estudios sobre Oriente antiguo (1986 - 1996) (Isimu 1, Revista sobre Oriente Próximo y Egipto en la antigüedad, Madrid), pp. 143 - 155.

Boucharlat, R. 1998b, “A la recherche d'Ecbatane sur Tappeh Hegmataneh”, Iranica Antiqua, XXXIII, pp. 173-186.

Boucharlat, R., 2005, "Iran”, in P. Briant - R. Boucharlat (eds.), L'archéologie de l'empire achéménide: nouvelles recherches (Persika 6), pp. 221- 292.

Boucharlat, R., 2012, "Tappeh Hegmataneh and Ancient Ecbatana", in H. Fahimi and K. Alizadeh (eds), Nāmvarnāmeh, Papers in honour of Massoud Azarnoush, Tehran, IranNegar, pp. 119-130.

Boucharlat, R., 2014, "Fire altars and fire temples in the $1^{\text {st }}$ Mill. BC-AD in the Iranian world", in P. Bielinski et al. (eds.), 8th International Congress on the Archaeology of the Ancient Near East, Harrassowitz, pp. 5-23.

Boucharlat, R., in press, "Arriving at Persepolis, an Unfortified Royal Residence", in E.R.M.Dusinberre and M.B. Garrison eds., Festschrift Margaret C. Root, (Achaemenid History XVI).

Boucharlat, R., 2018, Les traces archéologiques des palais achéménides de Hamadan ARTA 2018-002, p. 34. http://www.achemenet.com/pdf/arta/ARTA_2018.002_Boucharlat. pdf

Boucharlat, R. and Fazeli Nashli, H. eds. 2009, Tang-i Bulaghi Reports, Arta 2009.001- 2009.006, p. 109. www.achemenet.com/document/2009.001-Fazeli.pdf to 2009.006.pdf

Boucharlat, R., De Schacht, T., Gondet, S., 2012, "Surface Reconnaissance in the Persepolis Plain (2005-2008). New Data on the City Organisation and Landscape Management", in G.P. Basello and A.V. Rossi (eds.) Persepolis and his Settlements. Territorial System and Ideology in the Achaemenid State. Proceedings of the conference held in Viterbo, 16-17th December 2010. (Series Minor 77), Università degli Studi di Napoli “L'Orientale”, Napoli, pp. 183-224.

Carter, E., 1996, Excavations at Anshan (Tal-e Malyan): The Middle Elamite Period. Malyan Excavation Reports vol. 2. (University Museum Monongraphs 82), Philadelphia.

Gnoli, G., 1993, s.v.« Dahan-e Golaman », Encyclopaedia Iranica, Vol. VI, Fasc. 6, pp. 582-585. http://www.iranicaonline.org/articles/dahan-e-golaman

Gopnik, H \& Rothman, M., 2011, On the High Road, The History of Godin Tepe, Iran, The Royal Ontario Museum, Toronto and Mazda Publishers

Haerinck, E. and Overlaet, B., 1996 - 2010, Luristan Excavations Documents, vol. I - VIII (Acta Iranica XIX onwards), Peeters, Leuven.

Hassanzadeh, Y \& Mollasalehi, H., 2011, "New Evidence of Mannean Art: An Assessment of Three Glazed Tiles from Qalaichi (Izirtu)", in Álvarez Mon, J. and M. B. Garrison (eds.), pp. 407-417.

Helwing, B., Vatandoust, A., Parzinger, H. (eds.), 2011, Early mining and metallurgy on the Western Central Iranian Plateau. The first five years of work. von Zabern, Mainz und Darmstadt (Archäologie in Iran und Turan, Band 9). 
Kaboli, M., 2000, “The Apadana Gateway at Shush”, Iran, 38, pp. 161-162.

Kleiss, W., Calmeyer, P. (eds.) 1996, Bisutun. Ausgrabungen und Forschungen in den Jahren 1963-1967 (Teheraner Forschungen VIII), Berlin.

Lamberg-Karlovsky, C.C, Potts, D.T. (Eds.), 2001. Excavations at Tepe Yahya, 1967 - 1975: The Third Millennium, (Bulletin of the American Schools of Prehistoric Research 45), Cambridge, Mass.

Lecomte, O., 2013, “Activités archéologiques françaises au Turkménistan”, in J. Bendezu-Sarmiento (ed.), L'archéologie française en Asie Centrale (Cahiers d'Asie Centrale 21/22), pp. 165-190.

Magee, P., Lamberg-Karlovsky, C.C., Grave, P., 2004, Excavations at Tepe Yahya, Iran 1967-1975: The Iron Age Settlement, Cambridge, Mass.

Mahfrouzi, A and Piller, Ch., 2009, "First preliminary report on the joint IranianGerman excavations at Gohar Tappe, Māzandarān, Iran”, AMIT 41, pp. 177-2008

Majidzadeh, Y, Perrot, J., 2004, "Récentes découvertes à Jiroft (Iran): résultats de la campagne de fouilles 2004 (note d'information)", Comptes rendus de l'Académie des Inscriptions et Belles-Lettres 148, 3, pp. 1105-1117.

Moghaddam, A, 2012, Later Village Period Settlement Development in the Karun River Basin, Upper Khuzestan Plain, Greater Susiana, Iran, Oxford Archaeopress (BAR International series 2347).

Moghaddam, A., 2016, "A Fifth Millennium BC Cemetery in the North Persian Gulf: Zohreh Prehistoric Project”, Antiquity 90, No. 353. October 2016e3: 1-6.

Mohammadkhani, K., 2012, "Une nouvelle construction monumentale achéménide à Dahaneh-e Gholaman, Sistan, Iran", Arta 2012.001, http://www.achemenet.com/pdf/ arta/2012.001-Mohammadkhani.pdf

Moradi, Y., 2016, "On the Sasanian Fire temples: New Evidence from the Čahār tāq of Mil-e Milagah", Parthica 18, pp. 73-95.

Mortensen, P., 2014, Excavations at Tepe Guran: The Neolithic Period (Acta Iranica 55), Peeters, Leuven.

Naseri, R., Malekzadeh, M; \& Naseri, A., 2016, "Gūnespān: a late Iron Age site in the Median heartland", Iranica Antiqua 51, pp. 103-139.

Perrot, J., (ed.) 2010, Le Palais de Darius à Suse, une résidence royale entre Suse et Babylone, Paris, PUPS.

Perrot, J. et Majidzadeh, Y. (eds), 2003, Jiroft, fabuleuse découverte en Iran, Dossiers d'archéologie, 287.

Perrot, J et Majidzadeh, Y., 2005, L'iconographie des vases et objets en chlorite de Jiroft (Iran), Paléorient 31-2, pp. 123-152

Potts, D.T. (ed), 2013, The Oxford Handbook of Ancient Iran, Oxford University Press

Potts, D. \& Roustaei, K., C.A. Petrie, L.R. Weeks (eds) 2006, Mamasani, The Mamasani Archaeological Project Stage One. A report on the first two seasons of the ICAR -University of Sydney expedition to the Mamasani District, Fars Province, Iran, Bodleian Library, University of Oxford, BAR International Series 2044

Potts, D., Asgari Chaverdi, A., Petrie, C.A., Dusting, A., Farhadi, F., McRae, I.K., Shikhi, S., Wong, E.H., Lashkari, A. and Javanmard Zadeh, A., 2007, "The Mamasani Archaeological Project, Stage Two: Excavations At Qaleh Kali (Tappeh Servan/Jinjun [Ms 46])", Iran 45, pp. 287-300.

Potts, ; D.T ., Askari Chaverdi, A., McRae, I.K., Alamdari, K., Dusting, A., Jaffari, J., Ellicott, T.M., Setoudeh, A., Lashkari, A., Ameli Rad, Sh., Yazdani, A., 2009, "Further Excavations at Qaleh Qali (MS 46) by the Joint ICAR-University Of Sydney Mamasani expedition : Results of the 2008 Season", Iranica Antiqua 44, 207-282. 
Rahbar, M., 1998, “Découverte d'un monument d'époque sassanide à Bandian, Dargaz (Nord Khorassan). Fouille 1994 et 1995”, Studia Iranica, 27/ 2, pp. 213-250.

Rahbar, M., 2004, "Le monument sassanide de Bandiān: Un temple du feu d'après les dernières découvertes, 1996-1998", Studia Iranica, 33/1, pp. 7-30.

Rahbar, M., 2007, "A Tower of Silence of the sasanian Period at Bandiyan: some Observations about Dakhmas in Zoroastrian Religion", in J. Cribb \& G. Herrmann (eds), After Alexander. Central Asia before Islam ("Proc. of the British Academy 133), Oxford University Press, pp. 455-473.

Rezvani, H., Roustaei, K, Azadi, A ., Ghezelbash, E., 2007, Final report of the Archaeological excavations at Lamā Cemetery, Yasudj-Kohgiluyeh va Boyer Ahmad (Archaeological Report Monograph Series, 12), Tehran, I.C.A.R.(in Persian).

Sarraf, M. 2003, "Archaeological excavations in Tepe Ekbatana (Hamadan) by the Iranian Archaeological Mission between 1983 and 1999”, in G. Lanfranchi, M. Roaf and R. Rollinger (eds.) Continuity of Empire (?). Assyria, Media, Persia, Padova (History of the Ancient Near East/Monographs-V), pp. 271-279.

Sajjadi, S.M.S. \& Zebari, Z., 2018, "Dahaneh-ye Qolaman: building number 15", in S. Gondet et E. Haerinck (eds), L'Orient est son jardin. Hommage à Rémy Boucharlat (Acta Iranica 58), Peeters, Leuven, pp. 403-413.

Shishegar, 2006, Archaeological Report of Excavation at Surkh Dom-e Laki, Kuhdasht, Lorestan, $2^{\text {nd }}$ - 6th seasons 2001-2004, Archaeological Research Center, Tehran (in Persian, English summary).

Shishegar, A., 2015, Tomb of the Two Elamite Princesses of the House of King Shutur- Nahunte son of Indada, New Elamite Peeriod, Phase IIIB (Ca. 585-539 B.C.), Iranian Center for Archaeological Research, Tehran (in Persian, English summary).

Stronach, D.B., Roaf, M., 2007, Nush-i Jan I. The Major Buildings and the Median Settlement, The British Institute of Persian Studies \& Peeters, London - Leuven.

Sumner, W.M., 2003, Early urban life in the land of Anshan: Excavations at Tal-e Malyan in the highlands of Iran. Malyan Excavation Reports 3 (University Museum Monograph 117, Philadelphia 2003.

Vahdati, A., 2017, "Preliminary report on the Archaeological Survey in Esfarāyen county, Northeastern, Iran", AMIT, pp. 255-281.

Vahdati, A., 2018, "The Early Iron Age in northern Khorāsān”, in J. Lhuillier \& N. Boroffka, A Millennium of History. The Iron Age in southern Central Asia (2nd and 1st Millennia BC). Proceedings of the conference held in Berlin (June 23-25, 2014). Dedicated to the memory of Viktor Ivanovich Sarianidi. (Archäologie in Iran und Turan, 17 - Mémoires de la Délégation Archéologique française en Afghanistan 35), pp. 51-66. 